\title{
Technological Use in EFL Instruction: Investigating Teachers' Pedagogical Beliefs and Students' Learning Engagement
}

\author{
Ulfatul Ma'rifah, \\ Nurul Masrifah, \\ Yudhi Arifani \\ English Education Department, Universitas Muhammadiyah Gresik, Jl. \\ Sumatra 101 (GKB), Kebomas, Gresik, East Java, Indonesia, 61121 \\ ulfamarifah@umg.ac.id
}

Article History: Submitted on $14^{\text {th }}$ January 2021; Accepted on $12^{\text {th }}$ April 2021; Published on $30^{\text {th }}$ June 2021

\begin{abstract}
This exploration expected to discover the impact of EFL instructors' educational convictions on utilizing innovation on EFL understudies' learning commitment in the study hall and discover which academic conviction measurement most impacts EFL understudies' learning commitment in the homeroom. This is quantitative exploration with a review technique. Information were gathered from two online polls. Information examination strategies in this exploration utilized graphic insights and Structural Equation Modeling (SEM). In this exploration, respondents were $125 \mathrm{EFL}$ instructors and $125 \mathrm{EFL}$ understudies in a few auxiliary schools in the second semester of the 2019/2020 scholastic year in Gresik, East Java, Indonesia. This examination found that EFL educators' academic convictions as to utilizing innovation affect EFL understudies' learning commitment in the study hall (t-esteem is $10.840>1.96)$ and the educational conviction measurement most impacts EFL understudies' learning commitment in the homeroom is "Instructors' Practices with Regard to Using Technology" (t-esteem is $9.953>1.96$ )
\end{abstract}

Keywords: teachers' pedagogical beliefs, technology, students' learning engagement

\section{INTRODUCTION}

Technological advancements have an impact on every aspect of life, including in education. Technology can be used as a learning medium (Carle et al., 2009; Cutrim, 2008; Mann, 2008; Liu, 2011), and the use of technology in education is rising (e.g., Berrett et al., 2012; Inan \& Lowther, 2010; Tondeur et al., 2016). Unfortunately, not all EFL teachers take advantage of technological advancements to support learning English in the classroom 
(Hutchison \& Reinking, 2011; Tour, 2015). Besides due to external obstacles (Ertmer, 1999), namely factors related to technology (Ertmer, 2005; Kimmons et al., 2015), the main factor influencing technology usage in classroom learning is the teacher's belief (Palak \& Walls, 2009; Park \& Ertmer, 2007). Teachers' teaching practices in the classroom are strongly affected by their pedagogical beliefs (Fives \& Gill, 2015; Kagan, 1992; Pajares, 1992) so that in this case, EFL teachers will implement an English learning model that suits their pedagogical beliefs.

Pedagogical belief is defined as a belief and understanding of teachers about teaching and learning that are considered true (Tondeur et al., 2016). Pedagogical beliefs serve as filters that filter everything based on what teachers think is good and effective for learning (Ertmer, 2005; Palak \& Walls, 2009; Kagan, 1992; Liu, 2011; Tondeur et al., 2016; Ding et al., 2019). In general, teachers' pedagogical beliefs are grouped into teacher-centered belief and student-centered belief (Ravitz et al., 2000; Deng et al., 2014; Ding et al., 2019). Teacher-centered belief is usually based on behaviorism theory (Deng et al., 2014; Tondeur et al., 2016) and emphasizes on the delivery of information or knowledge or subject matter from teacher to students (Liu, 2011). Teacher acts as the one who assesses the correctness of students' work. Students are viewed as passive beneficiaries of confirmed information (Deng et al., 2014). Whereas, student-centered belief is usually based on constructivist theory and emphasizes students' responsibility to learn and engage in group work (Liu, 2011; Ertmer et al., 2012; Lim \& Chai, 2008). Teachers with student-centered belief will see teaching as a means of promoting the creation of meaning and interpretation by students of the phenomena they encounter (Deng et al., 2014).

The outcomes of research conducted by Tondeur et al. (2008) showed that EFL teachers with teacher-centered pedagogical beliefs tend to be less interactive in using technology to support learning English in the classroom (Ding et al., 2019). This is in line with previous research results that indicate that teachers with teacher-centered pedagogical belief do not use technology more often in classroom language learning than teachers with studentcentered pedagogical belief (Becker, 2000; Ertmer, 2005). While EFL teachers with student-centered pedagogical belief more often use and successfully integrate technology to support learning English in the classroom (Honey \& Moeller, 1990; Ertmer, 2005; Deng et al., 2014; Ding et al., 2019). Teachers with student-centered pedagogical belief use technology to retrieve information (Tondeur et al., 2008; Tondeur et al., 2016), deliver learning material, help students develop higher-order thinking, solve the problems (Berg, Ridenour Benz, Lasley, \& Raisch, 1998), support students' desire to apply knowledge and skills (Ananiadou \& Claro, 2009), and provide opportunities for students to operate available technology (Becker, 2000).

Because of the importance of technology, many studies have examined technology in English learning, including EFL teachers' pedagogical beliefs and practices using technology (Ding et al., 2019), the use of technology to 
increase learners' motivation in studying English, the use of technology to improve vocabulary, the use of technology to improve writing skills, etc. (Ding et al., 2019). One of these studies, namely research on EFL teachers' pedagogical beliefs and practices using technology (Ding et al., 2019), has benefited learning outcomes. Unfortunately, many researchers forget that learning success is not only influenced by EFL teachers' pedagogical beliefs and technology use but is also influenced by an important factor that exists between them, namely students' learning engagement (Webber, Krylow, \& Zhang, 2013).

Astin (1984) describes students' engagement as constructive energy for students to obtain academic experience as part of the classroom teaching and learning process in the context of both psychological and physical aspects (Arifani \& Suryanti, 2019). Learning engagement will create a conducive classroom environment and allow students to explore their potential ( $\mathrm{Hu} \&$ Kuh, 2002; Zhao et al., 2005). If students' learning engagement increases, it will affect learning outcomes and students' quality (Arifani \& Suryanti, 2019).

Several studies on engagement have been carried out. Fredricks et al. (2004) identified three engagement indicators of students' attitudes, emotions, and cognitive views. Zhao et al. (2005) validate the NSSE questionnaire to search for learning communities towards students' engagement. The outcome of the research revealed a strong and positive link to students' engagement. Trowler (2010) divides students' engagement into three categories, namely positive engagement, no engagement, and negative engagement. Roberts \& Mcneese (2010) examined the engagement of students to investigate whether they are graded into normal or transfer status depending on the status of the students. To gather the data, he employed the NSSE questionnaire. The outcomes showed that, relative to the transfer students, regular students were more involved. While other studies measured students' engagement in technology-based English learning without regard to teachers' pedagogical beliefs (Henrie, Halverson, \& Graham, 2015). Whereas teachers' pedagogical beliefs, the use of technology in teaching, and students' engagement are interrelated factors to achieve learning success. Therefore, this examination endeavors to connect EFL educators' instructive convictions with respect to utilizing innovation and learning accomplishment by focusing on understudies' learning commitment. So that in this examination, it will be seen the commitment of EFL educators' instructive convictions and works on utilizing innovation to understudies' learning commitment. Since understudies' learning commitment has a significant commitment in making learning progress (learning results). Thus, this exploration intended to address the accompanying inquiries:

1) Is there an influence of EFL teachers' pedagogical beliefs with regard to using technology on EFL students' learning engagement in the classroom? 
2) Which pedagogical belief dimension most influences EFL students' learning engagement in the classroom?

\section{METHOD}

The approach used in this research is quantitative approach with a survey method. This is an empirical study on EFL teachers and EFL students. The type of investigation in this research is causality. The time horizon in this research is cross-sectional.

In this research, the samples were taken by the proportionate stratified random sampling method. The respondents in this research were recruited through personal contact. The researchers reached EFL teachers who taught in junior high schools (grades 7 through 9), senior high schools (grades 10 through 12), and vocational high schools (grades 10 through 12) who used technology in their English teaching. 15\% of EFL teachers in secondary schools in Gresik or around 125 EFL teachers who used technology in teaching English in the classroom were asked to fill out an online questionnaire about EFL teachers' pedagogical beliefs concerning using technology in teaching English in the classroom. A total of 125 EFL students were also asked to fill out an online questionnaire about EFL students' learning engagement.

In this research, respondents were EFL instructors and EFL understudies in a few auxiliary schools in the second semester of the 2019/2020 scholastic year in Gresik, East Java, Indonesia. The quantity of respondents who partook in this exploration were 250 individuals who would then be able to be definite as follows:

Table 1:

Composition of Respondents by Profession

\begin{tabular}{ccc}
\hline Profession & Frequency & Percentage \\
\hline EFL Teachers & 125 & 50 \\
\hline EFL Students & 125 & 50 \\
\hline Total & 250 & 100 \\
\hline
\end{tabular}

Source: Primary data processed, 2020

Graphic 1:

Gender Diagram of EFL Teacher

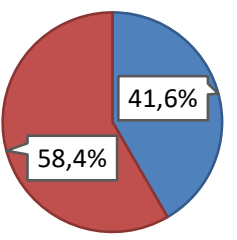

Graphic 2:

Gender Diagram of EFL Students

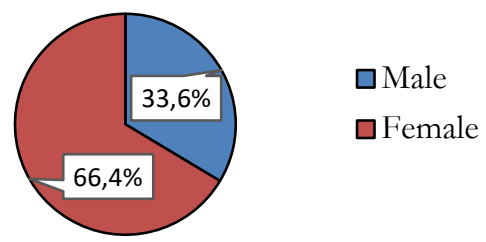


In this research, data were collected from two sources: (1) EFL teachers' pedagogical beliefs questionnaire concerning using technology in teaching English in the classroom and (2) EFL students' learning engagement questionnaire.

EFL teachers' pedagogical beliefs questionnaire with regard to using technology. This questionnaire consists of teacher belief inventory and teachers' practices concerning using technology. Teacher belief inventory was adopted from Johnson (1992). Johnson's (1992) framework is used in this research better to understand the orientation of EFL teachers' pedagogical beliefs. Specifically, its categories and explanations concentrate on teaching English as a second or foreign language. Other studies that investigate the beliefs of language teachers and the education of second language teachers have recently used this framework (e.g., Farrell, 2015; Tang et al., 2012) and also is used to examine EFL teachers' pedagogical beliefs and their teaching practices concerning using technology in the context of teaching English as a second language (Ding et al., 2019). Johnson (1992) classifies EFL teachers' pedagogical beliefs into 3 orientations: skill-based belief orientation (concentrating on the replication and memorization of patterns in native language), rule-based belief orientation (concentrating on the understanding the laws of grammar), and function-based belief orientation (concentrating on communicative contexts using the target language) (Ding et al., 2019). This instrument has been reviewed by experts to ensure its validity (Ding et al., 2019). While the items/indicators on the teachers' practices with regard to using technology are adopted from the coding scheme developed based on the orientation of English teachers' pedagogical belief and second language teaching literature (Ertmer et al., 2012; Farrell \& Lim, 2005; Johnson, 1992; Lim \& Chai, 2008; Nishino, 2008; Ding et al., 2019) to find out the pedagogical beliefs of English teachers and their teaching practices.

EFL students' learning engagement questionnaire. The researchers made a questionnaire about EFL students' learning engagement related to EFL teachers' pedagogical beliefs. There are 10 items that must be answered by EFL students. The researchers provide five response options (i.e., never, seldom, sometimes, often, and very often).

The development of instruments is pursued in several ways, they are; (1) arranging instruments' items/indicators; (2) translating instruments by linguists; (3) testing instruments; and (4) testing the validity and reliability of the instruments.

After the instruments were tested on several EFL teachers and EFL students in several secondary schools in Gresik, East Java, Indonesia. Then, the instruments were tested for validity and reliability with the confirmatory factor analysis test. Furthermore, the questionnaires distributed to respondents, 
for this situation, were EFL educators and EFL understudies in a few auxiliary schools in the second semester of the 2019/2020 scholarly year in Gresik, East Java, Indonesia. The analysts additionally speak with respondents to guarantee the objectivity/genuineness of rounding out the surveys. The aftereffects of the dissemination of polls were then organized utilizing a Likert Scale. In the following stage, the appropriate responses from the surveys were tried utilizing the AMOS approach form 23 with way investigation, discovered (research discoveries), talked about, and deciphered as per the examination.

The methods of data analysis in this research use descriptive statistics and SEM (Structural Equation Modeling). The analysis process uses AMOS (Analysis Moment of Structural) application program through the structural model.

Descriptive statistical analysis is used to describe respondents' responses to the research questionnaire in general. Descriptive statistical analysis is performed on each indicator in a construct. This research uses a minimum score of 1 and a maximum score of 5 . If divided into 3 criteria, the categories are as follows: (each category has a range of $4 / 3=1.33$ )

$1-2.33=$ Low

$2.34-3.66=$ Medium

$3.67-5=$ Height

\section{FINDINGS AND DISCUSSION}

Pedagogical belief variable is measured using 30 items/indicators divided into two dimensions, they are teacher belief inventory and teachers' practices concerning using technology. Teacher belief inventory (IKG) consists of IKG1-IKG15 indicators, while teachers' practices with regard to using technology (PPT) consist of PPT1-PPT15 indicators as shown in the figure below:

Graphic 3:

Diagram of Pedagogical Belief Variable

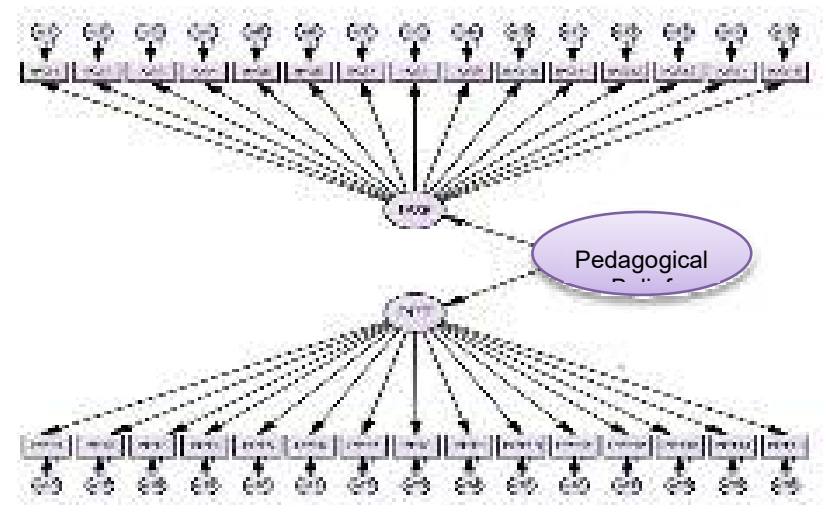


Based on the pedagogical belief variable diagram above then a questionnaire was made. To get a clear description of respondents' perceptions of pedagogical belief variable, an analysis was done with SPSS version 17. The result shows that the standard deviation values for each indicator are much lower than the average value. This shows that there is no variation in responses among respondents. Most of the respondents responded to the category of "moderate" (values ranging between 2.34 - 3.66) on indicators of the pedagogical belief variable. It indicates that EFL teachers in several secondary schools in the second semester of the 2019/2020 academic year in Gresik, East Java, Indonesia agreed with the indicators forming the pedagogical belief variable mentioned in the questionnaire.

Learning engagement variable is measured using 10 items/indicators consisting of KB1-KB10 indicators as shown in the figure below:

Graphic 4:

Diagram of Learning Engagement Variable

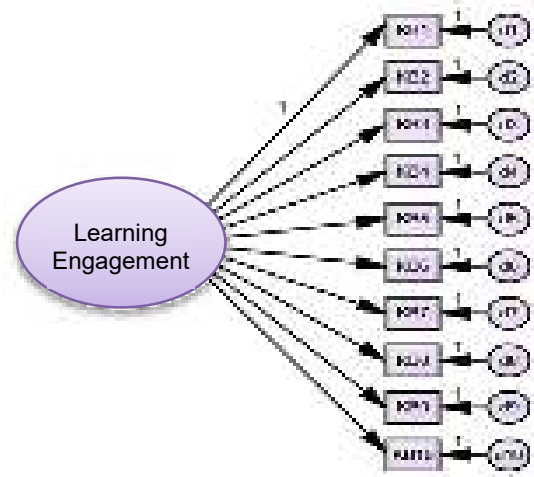

Based on the learning engagement variable diagram above then a questionnaire was made. To get a clear description of respondents' perceptions of the learning engagement variable, an analysis was done with SPSS version 17. The result shows that the standard deviation values for each indicator are much lower than the average value. This shows that there is no variation in responses among respondents. Most of the respondents responded to the category of "moderate" (values ranging between 2.34 - 3.66) on indicators of the learning engagement variable. It demonstrates that EFL understudies in a few optional schools in the second semester of the 2019/2020 scholastic year in Gresik, East Java, Indonesia concurred with the pointers framing the learning commitment variable referenced in the questionaries 


\section{Inferential Analysis: Structural Equation Modeling (SEM)}

The confirmatory factor analysis (CFA) technique is used to test the unidimensional of exogenous and endogenous constructs. The construct in this research consisted of the pedagogical belief variable and learning engagement variable. The confirmatory factor analysis (CFA) results of the research construct were obtained from eleven iterations/stages to obtain a fit research model. The following will be displayed the first iteration and the eleventh iteration (the model that has been fit).

\section{Graphic 5:}

CFA of Research Construct (Pedagogical Belief and Learning Engagement)_1 ${ }^{\text {st }}$ Iteration

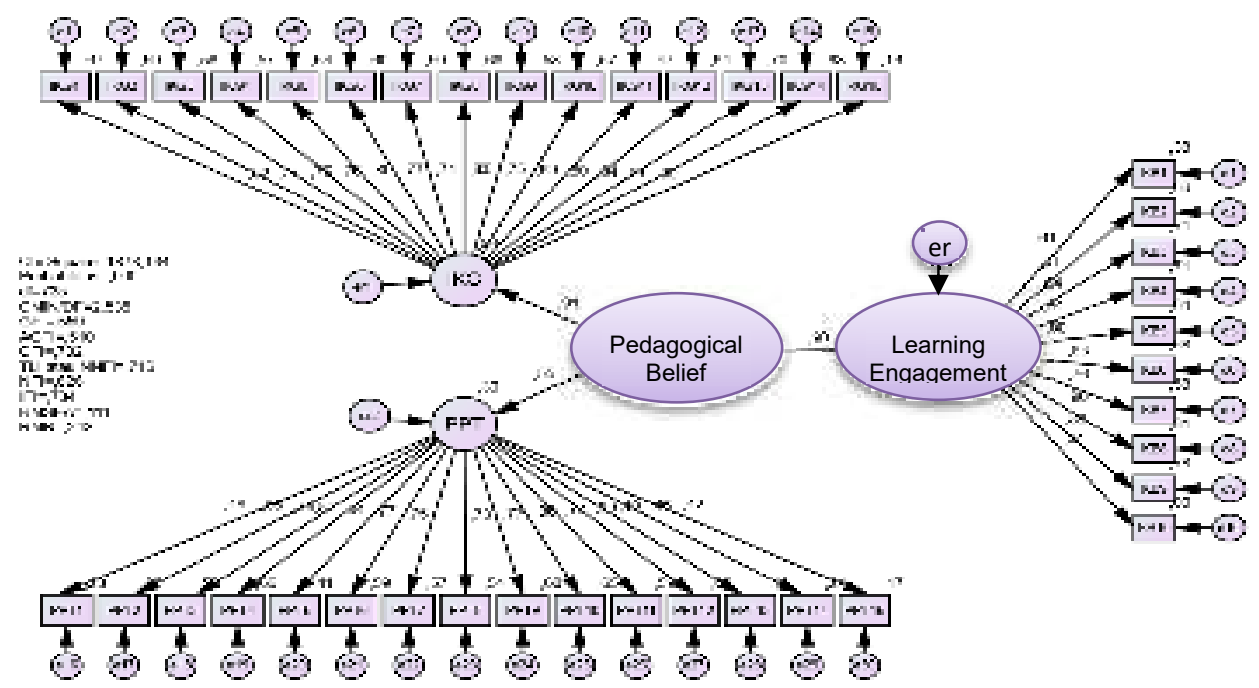

Source: Primary data processed, 2020

The figure above shows that the probability value is still below 0.05 , which means that the model is not yet fit. However, in SEM, the probability value or chi-square is not the only indicator so that it can use other parameters. The other parameter value is the loading factor of each indicator. It is still below 0.5 so that the modification made is to give a positive value with an impose of 0.01 in each dimension or indicator according to the advice from the output. Modifications made include removing indicators that are over-estimated or have LF values below $0 \mathrm{~m} .5$. After several modifications made until 11 iterations or stages, it is found that the research model figure that is fit is figure 6. Whereas the other iterations or stages of the CFA construct of this research can be seen in the appendix in this research. The following is the confirmatory factor analysis of the research construct that is fit (11 ${ }^{\text {th }}$ iteration): 
Graphic 6:

CFA of Research Construct (Pedagogical Belief and Learning Engagement)_11 ${ }^{\text {th }}$ Iteration/fit

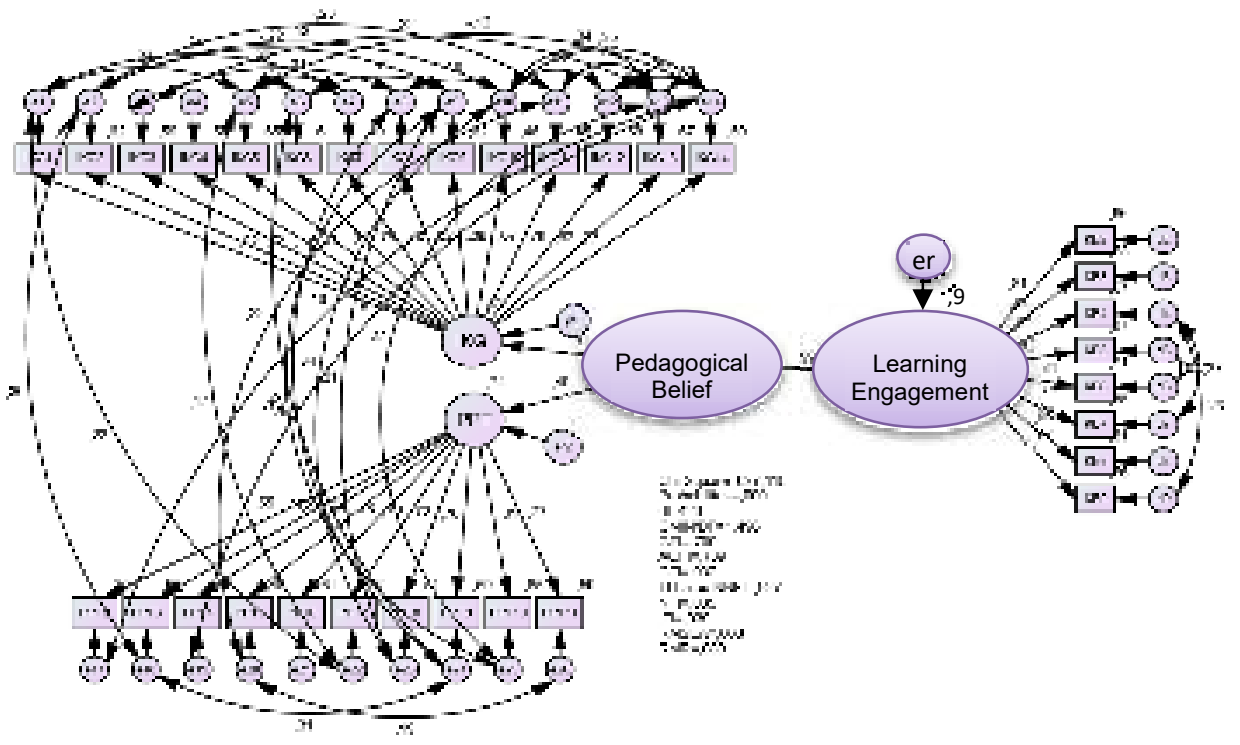

Source: Primary data processed, 2020

The figure above identifies that the research construct model already has parameter values (loading factor of each indicator and dimension) that are above 0.5 so that it can be concluded that the model is acceptable. Then, the researchers test the feasibility of the model for CFA research (pedagogical belief and learning engagement) based on the goodness of fit index (GOF) using AMOS 23. Most of the test results based on GOF have a good model fit. Therefore, Full Model_Fit is feasible and can be used to analyze the results of the research. In empirical research, a researcher is not required to fulfill all the criteria for goodness of fit, but it depends on each researcher's decision. Hair et al. (2010) said that to determine the viability of a model, the use of 4-5 goodness of fit criteria was considered adequate. Thus, it can be concluded that overall the model is acceptable and can be used for the preparation of substructure and structural equations and hypothesis testing proposed in this research.

The researchers evaluated the structural model using the estimated value of Standardized Regression Weight using AMOS 23. The results showed that all $t$-values of loading factor are greater than 1.96 and all standard loading factor values are greater than 0.5. Thus, it can be concluded that all dimensions and indicators on Full Model_Fit are significant and valid. The researchers also evaluated the validity of the indicators and the results showed that all items/indicators have good validity.

Construct Reliability (CR) and Variance Extract (VE) have also been tested and the results showed that the Construct Reliability (CR) of all 
constructs and dimensions have met the recommended value (CR $\geq 0.7)$. The Variance Extract (VE) of all constructs and dimensions also have met the recommended value (VE $\geq 0.5$ ). Thus, it can be concluded that all constructs and dimensions in Full Model_Fit have good reliability.

The structural model analysis is related to the evaluation of the coefficients or parameters that show the causal relationship or the effect of one latent variable on another latent variable. These causal relationships are hypothesized in research. Evaluation of structural models includes coefficient or parameter values. T-values of the coefficients or parameters are taken from the AMOS output. While the table below is a tabulation made by researchers based on the AMOS output:

Table 2:

Results of Evaluation of the Structural Model Coefficients (Standardized)

\begin{tabular}{llcccc}
\hline Path & $\begin{array}{c}\text { Standardized } \\
\text { Estimate }\end{array}$ & $\begin{array}{c}\text { T- } \\
\text { value/ } \\
\text { C.R. }\end{array}$ & $\begin{array}{c}\text { P- } \\
\text { value }\end{array}$ & Conclusion \\
\hline 1. & $\begin{array}{l}\text { Pedagogical Belief } \rightarrow \\
\text { Learning Engagement }\end{array}$ & 0.936 & 10.840 & $* * *$ & Significant \\
\hline 2. $\begin{array}{l}\text { Pedagogical Belief } \rightarrow \\
\text { Teacher Belief } \\
\text { Inventory (IKG) }\end{array}$ & 0.298 & 4.353 & $* * *$ & Significant \\
\hline $\begin{array}{l}\text { Pedagogical Belief } \rightarrow \\
\text { Teachers' Practices } \\
\text { with Regard to Using } \\
\text { Technology (PPT) }\end{array}$ & 0.928 & 9.953 & $* * *$ & Significant \\
\hline
\end{tabular}

Whereas the value of coefficient of determination $\left(\mathrm{R}^{2}\right)$ in this research is taken from the output of AMOS squared multiple correlations in the table below:

Table 3:

Output Squared Multiple Correlations

\begin{tabular}{lr}
\hline & Estimate \\
\hline Learning_Engagement & 0.989 \\
\hline
\end{tabular}

A structural equation model of research can be formed using standardized estimated values.

Structural Equation:

Learning Engagement $=0.994 *$ Pedagogical Belief + e, with $\mathrm{R}^{2}=0.989$ follows:

The coefficient of determination $\left(\mathrm{R}^{2}\right)$ and its interpretation are as

- The structural equation has $\mathrm{R}^{2}$ of 0.989 which means that $99 \%$ of the learning engagement construct variations can be explained by the 
variations in the pedagogical belief construct. In other words, the contribution of pedagogical belief to learning engagement is $99 \%$.

From the investigation, it was discovered that EFL educators' educational convictions as to utilizing innovation affect EFL understudies' learning commitment in the homeroom (t-esteem is $10.840>1.96$ ), and instructive conviction measurement most impacts EFL understudies' learning commitment in the study hall is "Instructors' Practices with Regard to Using Technology" (t-esteem is $9.953>1.96$ ).

Based on the results of the questionnaire obtained, most EFL teachers in several secondary schools in Gresik have pedagogical beliefs that are oriented to rule-based belief. Only a few EFL teachers have pedagogical beliefs oriented to function-based belief. Rule-based belief orientation focuses on students' understanding of grammatical rules. This shows that most EFL teachers in several secondary schools in Gresik still use the old paradigm, which assumes that if a person masters grammatical rules, it means he has high English proficiency. Even though this is contrary to the main function of a language, which is to communicate. The most important thing is not mastering grammar, but understanding the use of the language to communicate. Perhaps many EFL teachers apply what they used to get at school or campus, namely being taught grammar first and then using the language to communicate. There needs to be a paradigm shift among EFL teachers that the real purpose of learning a language is to be able to use that language to communicate (function-based belief orientation) so that students can be more active in language learning in the classroom.

In terms of using technology in EFL instruction, EFL teachers realize that technology has a significant effect on students' learning engagement( (Carle et al., 2009; P. J. Hu \& Hui, 2012; Tour, 2015) showed that learning using technology can make students' learning effectiveness, satisfaction, a general positive relationship between the use the learning technology and student engagement and learning outcomes. Based on those statement it can bee seen that this research have similarity statement as the previous research. However, the results of the questionnaire revealed that the majority of EFL teachers in several secondary schools in Gresik use technology to teach grammar. This research indicate that research participant only focus on the structural grammatical so assignment focus on the grammar. Unfoutunately, this statement contras with the communicative approach which is concerned with the function of the use of language does not focus on the grammar used.(Kim, 1972; Nakatani, 2002). They think that the most important thing is grammar. And only a few EFL teachers use technology to create interactive and communicative learning activities (function-based). This indicates that the main problem lies on EFL teachers' pedagogical beliefs.

Before this current study, there has been limited research that discusses the influence of EFL teachers' pedagogical beliefs with regard to using technology on EFL students' learning engagement in the classroom. Most of 
the previous studies only focused on EFL teachers' beliefs (pre-service and in-service teachers) and teaching practices (Zheng, 2009; Ding et al., 2019) and measured students' engagement in technology-based English learning without regard to teachers' pedagogical beliefs (Henrie et al., 2015).

\section{CONCLUSION}

This exploration analyzed the impact of EFL instructors' academic convictions concerning utilizing innovation on EFL understudies' learning commitment in the study hall. This examination uncovered a huge impact of EFL educators' educational convictions as to utilizing innovation on EFL understudies' learning commitment in the homeroom in a few optional schools in the second semester of the 2019/2020 scholarly year in Gresik, East Java, Indonesia. While educational conviction measurement most impacts EFL understudies' learning commitment in the study hall is "Educators' Practices with Regard to Using Technology".

Based on the results, from several pedagogical belief orientations, namely skill-based belief orientation, rule-based belief orientation, and function-based belief orientation, the majority of EFL teachers in several secondary schools in Gresik have pedagogical beliefs that are rule-based orientations. They have also realized the importance of integrating technology into learning English in the classroom and involving students during learning. Unfortunately, they still use the old paradigm that prioritizes grammar teaching and assumes that someone who masters grammar means proficient in English. Even though this is contrary to the main objective of language learning, it is to use the target language to communicate. In this respect, the main problem lies on EFL teachers' pedagogical beliefs. EFL teachers must realize that their beliefs will influence their use of technology in English learning activities in the classroom. Therefore, it is necessary to change the paradigm and point of view of EFL teachers.

Although several previous studies have discussed the relationship between teachers' pedagogical beliefs and technology integration practices (e.g., Ertmer et al., 2012; Ding et al., 2019), further research is suggested to discuss the impact of teachers' pedagogical beliefs on the implementation of technology use as an English learning medium. Furthermore, for EFL teachers, to more frequently integrate technology to achieve the objectives of learning English and engage students in interactive and communicative learning activities such as group discussion, question and answer activities in meaning-making, and other interactive activities related to English culture. It is intended to make students actively engaged in learning activities, and also learning objectives can be achieved. 


\section{REFERENCES}

Ananiadou, K., \& Claro, M. (2009). 21 st century skills and competences for new millennium learners in OECD countries. OECD Education Working Papers.

Arifani, Y., \& Suryanti, S. (2019). The influence of male and female ESP teachers' creativity toward learners' involvement. International Journal of Instruction. http://doi.org/10.29333/iji.2019.12116a

Astin, A. W. (1984). Student involvement: A developmental theory for higher education. Journal of College Student Development, (July), 518.

Becker, H. J. (2000). Findings from the teaching, learning, and computing survey: Is Larry Cuban right? Education Policy Analysis Archives.

Berg, S., Ridenour Benz, C., Lasley, T. J., \& Raisch, C. D. (1998). Exemplary technology use in elementary classrooms. Journal of Research on Computing in Education, 31(2), 111-122. http://doi.org/10.1080/08886504.1998.10782245

Berrett, B., Murphy, J., \& Sullivan, J. (2012). Administrator insights and reflections: Technology integration in schools. Qualitative Report, 17(1), 200-221.

Carle, A. C., Jaffee, D., \& Miller, D. (2009). Engaging college science students and changing academic achievement with technology: A quasi-experimental preliminary investigation. Computers and Education, 52(2), 376-380. http://doi.org/10.1016/j.compedu.2008.09.005

Cutrim, E. S. (2008). Using a voting system in conjunction with interactive whiteboard technology to enhance learning in the English language classroom. Computers and Education, 50(1), 338-356. http://doi.org/10.1016/j.compedu.2006.07.001

Deng, F., Chai, C. S., Tsai, C. C., \& Lee, M. H. (2014). The relationships among chinese practicing teachers' epistemic beliefs, pedagogical beliefs and their beliefs about the use of ICT. Educational Technology and Society.

Ding, A. C. E., Ottenbreit-Leftwich, A., Lu, Y. H., \& Glazewski, K. (2019). EFL Teachers' Pedagogical Beliefs and Practices With Regard to Using Technology. Journal of Digital Learning in Teacher Education. http://doi.org/10.1080/21532974.2018.1537816

Dray, B. J., Lowenthal, P. R., Miszkiewicz, M. J., Ruiz-Primo, M. A., \& Marczynski, K. (2011). Developing an instrument to assess student readiness for online learning: A validation study. Distance Education, 32(1), 29-47. http://doi.org/10.1080/01587919.2011.565496

Ertmer. P.A. (1999). Addressing first- and second-order barriers to change: strategies for technology integration. Educational Technology Research and Development, 47(4), 47-61.

Ertmer, P. A. (2005). Teacher pedagogical beliefs: The final frontier in our quest for technology inteErtmer, P. A. (2005). Teacher pedagogical beliefs: The final frontier in our quest for technology integration? 
Educational Technology Research and Development, 53(4), 25-39. h. Educational Technology Research and Development, 53(4), 25-39.

Ertmer, P. A., Ottenbreit-Leftwich, A. T., Sadik, O., Sendurur, E., \& Sendurur, P. (2012). Teacher beliefs and technology integration practices: A critical relationship. Computers and Education, 59(2), 423435. http://doi.org/10.1016/j.compedu.2012.02.001

Farrell, T., \& Lim, P. (2005). Conceptions of Grammar Teaching: A Case Study of Teachers' Beliefs and Classroom Practices. Tesl-Ej, 9(2), 1-13.

Farrell, T. S. C. (2015). Promoting Teacher Reflection in Second Language Education: A Framework for TESOL Professionals. New York, NY: Routledge, 12(1).

Fives, H., \& Gill, M. G. (2015). International handbook of research on teachers' beliefs. Routledge, Taylor \& Francis Group. New York: Routledge. http://doi.org/10.4324/9780203108437

Fredricks, J. A., Blumenfeld, P. C., \& Paris, A. H. (2004). School Engagement Potential of The Concept. Review of Educational Research, 74(1), 59-109.

Hair, J. F., Black, W. C., Babin, B. J., \& Anderson, R. E. (2010). Multivariate Data Analysis (Seventh Edition). Pearson (7th ed.). Pearson.

Henrie, C. R., Halverson, L. R., \& Graham, C. R. (2015). Measuring student engagement in technology-mediated learning: A review. Computers and Education, 90, 36-53. http://doi.org/10.1016/j.compedu.2015.09.005

Honey, M., Moeller, B. (1990). Teachers' Beliefs and Technology Integration: Different Values, Different Understandings. Center for Technology in Education, Technical Report n.6.

Hu, P. J., \& Hui, W. (2012). Examining the role of learning engagement in technology-mediated learning and its effects on learning effectiveness and satisfaction. Decision Support Systems, 53(4), 782-792. http://doi.org/10.1016/j.dss.2012.05.014

Hu, S., \& Kuh, G. D. (2002). Being (dis)engaged in educationally purposeful activities: The influences of student and institutional characteristics.

Research in Higher Education, 43(5), 555-575.

http://doi.org/10.1023/A:1020114231387

Hutchison, A., \& Reinking, D. (2011). Teachers' perceptions of integrating information and communication technologies into literacy instruction: A national survey in the United States. Reading Research Quarterly, 46(4), 312-333. http:// doi.org/10.1002/RRQ.002

Inan, F. A., \& Lowther, D. L. (2010). Factors affecting technology integration in K-12 classrooms: A path model. Educational Technology Research and Development, 58(2), 137-154. http://doi.org/10.1007/s11423-009-9132-y

Johnson, K. E. (1992). The Relationship between Teachers' Beliefs and Practices during Literacy Instruction for Non-Native Speakers of English. Journal of Literacy Research, 24(1), 83-108. http://doi.org/10.1080/10862969209547763 
Kagan, D. M. (1992). Professional Growth Among Preservice and Beginning Teachers. Review of Educational Research, 62(2), 129-169. http://doi.org/10.3102/00346543062002129

Kim, Y. Y. (1972). A communication approach to the acculturation process: Astudy of Korean Immigrants In Chicaho.

Kimmons, R., Miller, B. G., Amador, J., Desjardins, C. D., \& Hall, C. (2015). Technology integration coursework and finding meaning in pre-service teachers' reflective practice. Educational Technology Research and Development, 63(6), 809-829. http://doi.org/10.1007/s11423-0159394-5

Lim, C. P., \& Chai, C. S. (2008). Teachers' pedagogical beliefs and their planning and conduct of computer-mediated classroom lessons. British Journal of Educational Technology, 39(5), 807-828. http://doi.org/10.1111/j.1467-8535.2007.00774.x

Liu, S. H. (2011). Factors related to pedagogical beliefs of teachers and technology integration. Computers and Education, 56(4), 1012-1022. http://doi.org/10.1016/j.compedu.2010.12.001

Mann, B. L. (2008). The evolution of multimedia sound. Computers and Education, 50(4), 1157-1173. http://doi.org/10.1016/j.compedu.2006.11.002

Nakatani, Y. (2002). Identifying Strategies That Facilitate EFL Learners' Oral Communication: A Classroom Study Using Multiple Data Collection Procedures, (1998).

Nishino, T. (2008). Japanese Secondary School Teachers' Beliefs and Practices Regarding Communicative Language Teaching: An Exploratory Survey. JALT Journal, 30(1), 27-51.

Pajares, M. F. (1992). Teachers' Beliefs and Educational Research: Cleaning Up a Messy Construct. Review of Educational Research, 62(3), 307-332. http://doi.org/10.3102/00346543062003307

Palak, D., \& Walls, R. T. (2009). Teachers' Beliefs and Technology Practices. Journal of Research on Technology in Education, 41(4), 417-441. http://doi.org/10.1080/15391523.2009.10782537

Park, S. H., \& Ertmer, P. A. (2007). Impact of problem-based learning (PBL) on teachers' beliefs regarding technology use. Journal of Research on Technology in Education, 40(2), 247-267. http://doi.org/10.1080/15391523.2007.10782507

Ravitz, J., Becker, H., \& Wong, Y. (2000). Constructivist-Compatible Beliefs and Practices among US Teachers. Teaching, Learning, and Computing: 1998 National Survey Report\# 4. Center for Research on Information Technology and Organizations University of California, Irvine And University of Minnesota, 69.

Roberts, J., \& Mcneese, M. N. (2010). Student Involvement / Engagement in Higher Education Based on Student Origin. Research in Higher Education Journal, 7, 1-11.

Tang, E. L. Y., Lee, J. C. K., \& Chun, C. K. W. (2012). Development of 
teaching beliefs and the focus of change in the process of pre-service ESL teacher education. Australian Journal of Teacher Education, 37(5), 90107. http://doi.org/10.14221/ajte.2012v37n5.8

Tondeur, J., Hermans, R., van Braak, J., \& Valcke, M. (2008). Exploring the link between teachers' educational belief profiles and different types of computer use in the classroom. Computers in Human Behavior, 24(6), 2541-2553. http://doi.org/10.1007/s11423-016-9481-2

Tondeur, J., van Braak, J., Ertmer, P. A., \& Ottenbreit-Leftwich, A. (2016). Understanding the relationship between teachers' pedagogical beliefs and technology use in education: a systematic review of qualitative evidence. Educational Technology Research and Development. http://doi.org/10.1007/s11423-016-9481-2

Tour, E. (2015). Digital mindsets: Teachers' technology use in personal life and teaching. Language Learning and Technology, 19(3), 124-139.

Trowler, V. (2010). Student engagement literature review. The Higher Education Academy, (November), 1-15.

Webber, K. L., Krylow, R. B., \& Zhang, Q. (2013). Does involvement really matter? Indicators of college student success and satisfaction. Journal of College Student Development, 54(6), 591-611. http://doi.org/10.1353/csd.2013.0090

Zhao, C.-M., Kuh, G. D., \& Carini, R. M. (2005). A Comparison of International Student and American Student Engagement in Effective Educational Practices. The Journal of Higher Education, 76(2), 209-231. http:// doi.org/10.1353/jhe.2005.0018

Zheng, H. (2009). A Review of Research on EFL Pre-Service Teachers' Beliefs and Practices. Journal of Cambridge Studies, 4(1), 73-81. 